\title{
TYPES AND FUNCTION OF CODE SWITCHING FOUND IN THE CONVERSATION OF DANIEL MANANTA AND RALINE SHAH ON "DANIEL TETANGGA KAMU" VIDEO YOUTUBE CHANNEL
}

\author{
Ni Made Adi Andani ${ }^{1}$, I Komang Sulatra ${ }^{2}$, I Made Indrawan Jendra ${ }^{3}$ \\ Mahasaraswati Denpasar University, Indonesia1, 2, 3 \\ adiandani50@gmail.com, \\ iwanindrawan300573@gmail.com \\ soelatra01@yahoo.com,
}

\section{Journal History}

Submitted 23rd December 2021 Revised 21 th January 2022 Accepted 23rd January 2022 Published 24th January 2022

Keywords:

Code Switching, Bilingualism, YouTube Channel

\begin{abstract}
This study has two purposes, those are to find out the types and functions of code-switching used in conversation between Daniel Mananta and Raline Shah in "Daniel Tetangga Kamu" video YouTube channel. A qualitative method is used for this study for analyzing the data collected from five videos. The method is applied to give a clear description of the data according to the three types of code switching. The result of this analysis showed that there were three types of code switching found in this conversation, including Tag switching, intra-sentential switching and inter-sentential switching. Type of code-switching which is intra-sentential switching is the most often used in conversation between Daniel Mananta and Raline Shah utterances because they was more comfortable when using words, clauses, and phrases in one sentence to convey motivational messages. Regarding the six functions of code switching, the analysis showed that there was six function of code switching are; referential, directive, expressive, phatic, metalinguistic and poetic. Metalinguistic is the dominant function of code-switching in conversation between Daniel Mananta and Raline Shah's utterances. It occurs because Daniel Mananta and Raline shah wanted to impress the other participants with a show of linguistic skill.
\end{abstract}




\section{INTRODUCTION}

Language is very important means of communication. It is used to communicate and to give information to others. There are many languages in the world that people can choose to interact. Choosing one proper language in communication is very important to avoid misunderstanding. People must choose a particular language and or decide to switch from one to another. The use of English in conversations on social media creates many kinds of phenomenon. One of them is code switching. A research in code switching is a study to understand why people do who are competent in two languages alternate in a particular conversation or situation. Code switching in generally is a phenomenon when a bilingual and multilingual speaker shifts from one language to another during conversation. Code switching is term in linguistic referring to use more than one language. Code switching based on Grosjean (1982) suggest definition of code switching as the use of more than one language by communication in speech act. As a part of bilingualism code switching is commonly found in any conversation, teaching, learning, or other kind of communication.

As early as 1981, Hamers as cited in Romaine (1995) differentiated between bilingualism and bilinguality. Bilinguality was posited as the psychological state of an individual who as access two more than one linguistic code as a means of social communication. The degree of access will vary long several dimensions which are psychological, sociological, cognitive, psycholinguistic, social psychological, sociological, sociolinguistic, sociocultural, and linguistic. The concept of bilingualism, on the other hand, includes that of bilinguality (or individual bilingualism), but refers community in which two languages are in contact, with the result that two codes can be used in the same interaction and that number of individuals are bilingual (societal bilingualism). In this case bilingualism is also known as code switching in sociolinguistics. At the time, code switching mostly used by artist, presenter, writer etc. to show their language, variety, and the dialect. It can be found on the television, radio, social media, novel, and books. Code switching can be happened in bilingual or multilingual society which occurs in the conversation in daily live. Nowadays social media is the famous place where we could find code switching because in social media ideas can be expressed through language used.

Social media is a site that provides a networking place for people to connect and when we talk about YouTube as a social media site. YouTube is a site of video sharing Code switching is also found in the "Daniel Tetangga Kamu" YouTube channel. In Daniel Mananta videos code switching phenomenon can be found easily because the host are able to speak English fluently. The variety of languages can be found in a show or 
a conversation in video YouTube channel. He sometimes uses a variety of language in presenting his contents YouTube channel, even mixing, or changing languages from one to another. In his YouTube content, Daniel Mananta usually talks to his guest stars, one of which is Raline Shah, in one in content they usually talk using code switching.

The author is interested in choosing this conversation because it is very interesting and talks about the life of Raline Shah. This conversation talks about the life experience of Raline Shah who was taught hard by her father from a young age and motivates us to always be grateful for what we have. Based on the reading of these videos, the author finds that the use of code switching is widely used in these videos. Therefore, Daniel Mananta's YouTube channel video deserves to be the object of analysis in this study. The author also hopes that this research on code switching can provide good and useful information for the audience. The author hopes that the audience can inspire and of course give them positive values.

To develop a scientific study, some previous study has been reviewed. In the first research entitled "Code Switching Used by Kimmy Jayanti in "iLook" Program in Net TV" (Rahmaniah 2016). Found that this study analyzes the most dominant types of code switching and the reasons of Kimmy Jayanti do code switching in the "iLook" program. The most dominant type used by Kimmy Jayanti in "iLook" program on NET TV was intra-sentential switching. Rahmaniah's study found all of seven reasons which are proposed by Hoffman (1992). And The last related literature the journal entitled "An Analysis Code Switching Used in the Novel "Dunia Mereka" (Tasar 2009). The study of Tasar discussed about code switching that focused on bilingual in the novel. He found that in the novel was study which emphasizes the type and the function why bilingual people switch their language. The code based on the dialogue between the characters.

\section{METHODS}

The researcher used the library research method in analyzing and describing the code-switching data contained in the conversations of Daniel Mananta and Raline Shah in "Daniel Tetangga Kamu" YouTube channel video. The video conversation between Daniel Mananta and Raline Shah on the "Daniel Tetangga Kamu" YouTube channel was used as a data source in this study. There are five video conversations between Daniel Mananta and Raline Shah. In the process of collecting data, researchers used the observation method to obtain detailed information. There are four steps in collecting data: (1) Open the YouTube app and find and search for videos. (2) Download the video, followed by listening and watching videos to find out the use of code switching. (3) Listening carefully and repeating what Daniel Mananta and Raline Shah said during the code- switching, followed by making a transcription of each Video. (4) Reading the transcription to choose code switching can be the best 
representation in analyzing the data. The data are described factually, systematically, and scientifically following the code switching theory proposed by Poplack (1980) as cited in Romaine (1989: 122) and Appel and Muysken (1987). The results of data analysis are presented formal and informal. Formal, the data is presented in tabular form to show the incidence and percentage of types of code switching and their functions. Informal, sentences are used to describe the data descriptively.

\section{RESULTS}

\section{RESULTS AND DISCUSSION}

The results of data analysis are presented formal and informal method to presents the data of analysis. Formal, the data is presented in tabular form to show the incidence and percentage of types of code switching and their functions. Informal, sentences are used to describe the data descriptively. The finding is divided into two parts: the first one is to show the finding of types of code-switching and the second is showing the finding of code-switching functions. The researcher analyzes the data based on the theory from Poplack (1980) as cited in Romaine (1989: 122) and Appel and Muysken (1987).

\section{DISCUSSION}

The total data in this analysis is 137 code switching. Based on the table there are $70(51.05 \%)$ data of intra-sentential switching. It becomes the most dominant types because intra-sentential switching involves arguably, the greatest syntactic risk, and maybe avoided by all but the most influence bilinguals, the Host and guest in "Daniel Your neighbor" YouTube Channel usually switches the code within a sentence in his utterances, there were also found 36 (26.19\%) data of inter-sentential, henceforth tag switching are the least of three types of code switching in this research, there were only $30(21.85 \%)$ data that found, which are indicated as tag switching.

Based on the data tabulation, metalinguistic function dominated where $39(30,61 \%)$ of total data are categorized as metalinguistic function, serves to indicate occurs when it's directly or indirectly used to comment on the language involved. It's happened when speaker's speech between different codes in order to impress the other participants with a show a linguistic skill, the speaker often do a code switching which is indicating as metalinguistic function in his utterances.

The result of finding is followed by $27(19,66 \%)$ of referential function, $27(19,66 \%)$ of phatic function, $20(14,55 \%)$ of expressive function and $11(7,94 \%)$ of directive function. Meanwhile, poetic function is only represented by $9(6,53 \%)$ it is because the speaker rarely inserts a joke, puns in his conversation, he only focuses on present the guest life and in one sentence there are more than one function. Here are the example and the explanation of the 3 types of code switching and it function found in 
the conversation between Daniel Mananta and Raline Shah in video YouTube channel.

\subsection{Tag Switching and Its Functions}

\section{Data 1}

"So, tetangga gue yang sangat gue sayangi, kasihi dan cintai." (so, My neighbor who I love )

(VIDEO V, 1.36)

The utterance above was categorized as tag switching which refers to switching that occur by using English expression as a tag in the first sentence "so" and it continues with Indonesia language by saying 'tetangga gue yang sangat gue sayangi, kasihi, cintai". Tag-switching involves inserting a tag or short phrase in one language into an utterance that is otherwise entirely in another language. The speaker tag English word to make the conversation is effective.

The switch of code from English language into Indonesian language occurred in the data above. The Indonesian clause by saying "tetangga gue yang sangat gue sayangi" is a kind of puns. In this case this analysis can be categorized as poetic function. The speaker intended to raise the viewers' attention about the puns that he said to make the situation more colorful.

\section{Data 2}

"Anyway, yuk kita lanjut obrolan kita Raline" (anyway, lets continue our conversation Raline.) (VIDEO V, 1.03)

In the utterances above the speaker uttered "anyway" in the beginning of the sentence, it can be categorized as a tag switching because it is a code-switching action when the speaker attaches or adds any tag or filler in a sentence. Tag-switching involves inserting a tag or short phrase in one language into an utterance that is otherwise entirely in another language. The tag uttered by the speaker using English Language, meanwhile the rest of his utterance used Indonesian Language.

The data above presents a kind of the function of code switching. The speaker switched the code from English language into Indonesian. Here, the speaker used the word "anyway" to start or open his explanation. It also emphasizes the tone when the speaker said "anyway". Therefore, it can be categorized as phatic function. 


\subsection{Inter-sentential switching and Its Functions}

\section{Data 3}

"I don't care about people, karena gue tau diri gue sendiri.

" (I don't care about people, because I know my self.) (VIDEO V, 1.54)

The utterance above can be categorized as inter-sentential switching since the data shows a switch between two languages, English to Indonesia which occurs in the first sentence. The speaker uttered the sentence by using English language for the first clause and the second clause use uttered in Indonesia language.

In the utterance above is also categorized as expressive function because in the beginning of the utterance there is a sentence "I don't care about people." which means express feeling from the speaker. The word above was used to express the feeling from speaker because she was confidence.

\section{Data 4}

"Jadi waktu kecil aku kan sering ke Afrika jadi, I'm used to going to jungle" (So when I was little I used to go to Africa, I'm used to going to jugle )

(VIDEO II, 14.49)

On the data above, the speaker used Indonesian language from the beginning of his utterance and then he switched into English language in the rest of his utterance. We can see that there is a complete sentence and then switched his language after finishing his first utterance. This can be classified into inter- sentential switching.

The purpose was the speaker wanted to impress the hearer or viewer since he could speak fluently by using two languages. It was used to show the speaker's opinion about life. Moreover, comment indirectly on the language involved was the other purpose of the speaker. This analysis indicates that code switching above holds function as metalinguistic

\subsection{Intra-sentential switching and Its Functions}

\section{Data 5}

"Tadi aku ada point sih setelah mendengar itu trus aku lupa Cuma I think that was beautiful what you said, thank you so much"

(I had a point earlier after hearing that I forgot but I think that was beautiful what you said, thank you so much)

(VIDEO V, 8.31)

The utterance above is classified into intra-sentential switching because the speaker used Indonesian language in the beginning of the 
utterance and then inserted a word "point" in English language and switched again into Indonesian language and the rest of his utterance he switched again into English language until full stop in the rest of the utterance.

Based on the function of code switching, it serves a function as directive function because the presenter has a point to the audience or the viewer about their conversation. It refers to the utterance "Tadi aku ada point sih setelah mendengar itu trus aku lupa Cuma I think that was beautiful what you said, thank you so much" By giving advices, it means the speaker involved the hearer directly since the speaker wanted the hearer to follow his advice.

\section{Data 6}

"Then I was like oh my god! There is something wrong with me, kayak aku nge- judge diri aku gitu"

(Then I was like oh my god! There is something wrong with me,like I judge my self this way)

(VIDEO V, 4.45)

The utterance above can be categorized as intra-sentential switching. Firstly, the speaker used English language and the switched into Indonesian language and he also inserted English word "judge" in Indonesian word. From that case, it can be categorized as intra-sentential switching because according to Poplack (1980) intra-sentential switching is switches the code within a sentence.

According to the function of code switching, it serves function as referential function because the speaker used the English word "judge" and inserted into Indonesian utterance. It happened due to the lack of knowledge of Indonesian language on the word "judge" in Indonesian language. In Indonesian language "judge" is "menilai". However, the word "judge" usually used by Indonesian speaker when they talk her life.

\section{CONCLUSION}

Code switching is the used between two languages in conversation. The people usually use code switching to make the utterances easier to be understood by the hearer. In this study which used the data source from Daniel Mananta and Raline Shah utterances on YouTube channel, it was found some types and the functions of code switching that interesting to be analyzed. There are three types of code switching according to Poplack (1980) are found in Daniel Mananta and Raline Shah utterances. Those are tag switching, inter-sentential switching, and intra-sentential switching. The result presented intra-sentential switching as the dominant occurrence of code switching in Daniel Mananta and Raline Shah utterances because as the result from the data Daniel Mananta and Raline Shah often do a code switching which is intra-sentential switching and got 70 data 
$(50,05 \%)$. Meanwhile, the lowest percentage is Tag switching, only 30 data $(21,85 \%)$ which means Daniel Mananta and Raline Shah rarely used Tag switching to avoid miss understanding because most of viewer is Indonesian and speaks Indonesian language also.

Meanwhile, for the function of code-switching from five videos in Daniel Mananta and Raline Shah utterance, the function of code switching based on theory purposed by Apple and Muysken (1987). There are six function of code switching those are refential function, directive function, expressive function, phatic function, metalinguistic function, and poetic function. The dominant occurrence is Metalinguistic function because in the data Daniel Mananta and Raline Shah functions because the speaker used English language in the rest of the sentence to impress the viewer that he could speaks English fluently. The author also got 27 data $(19,66 \%)$ from phatic function and the lowest occurrence in function of code switching is poetic function only 9 data $(6,53 \%)$ from five videos.

\section{REFERENCES}

Adi, Wiruma Titian. 2018. Code Switchin in Critical Eleven Novel. Journal. Jakarta: ABA BSI

Apple, R. \&Muysken, P. 1987. Language Contact and Bilingualism.London Edward Arnold.

Grosjean,Francois. 982.Life with Two language.

Combridge:HarvardUniversityPress.

Gumperz, Jhon Joseph. 1982. Discourse Strategies. Cambridge: Cambridge University Press.

Hoffmann, Charlotte. 1991. An Introduction to Billingualism. London: Longman.

Hymes, D. 1974. Foundation in sociolinguistic: an Ethnographic Approach.

Phildadhelpia:University of Pennsylvania.

Pianto.2013. "The Analysis on Code Switching Used in The Short Story of

"Kawanku" Magazine". Denpasar:English Study Program, STIBA Saraswati Denpasar.

Poplack, Shana. 1980. Sometimes I'll start a sentence in Spanish Termino

En Espanol: toward a typology of code-switching. 581-618.

Romaine, Suzanne. 1988. Billingualism. Oxford: Basil Blackwell.

Romaine, Suzanne. 1995. Billingualism. Second Edition: Oxford: Basil Blackwell. 